\title{
Effect of Shrimp Chitin and Shrimp Chitin Hydrolysate on the State of Water and Dehydration-induced Denaturation of Lizard Fish Myofibrillar Protein
}

\author{
Kingduean Somjit ${ }^{1}$, Kenji Hara ${ }^{2 *}$, Miki Yoshimura ${ }^{2}$, Nami Matsuo ${ }^{2}$, Orawan Kongpun ${ }^{3}$ \\ and Yukinori NOZAKI ${ }^{2}$ \\ ${ }^{1}$ Graduate School of Science and Technology, Nagasaki University, 1-14 Bunkyo-machi, Nagasaki, 852-8521, Japan \\ ${ }^{2}$ Faculty of Fisheries, Nagasaki University, 1-14 Bunkyo-machi, Nagasaki, 852-8521, Japan \\ ${ }^{3}$ Fishery Technological Development Division, Department of Fisheries, Kaset-Klang, Chatuchak, Bangkok 10900.
}

Received July 23, 2004; Accepted January 21, 2005

\begin{abstract}
To assess the potential utilization of shrimp waste, shrimp chitin (SC) and shrimp chitin hydrolysate (SCH) were prepared from black tiger (Penaeus monodon), endeavour (Metapenaeus endeavouri) and giant freshwater (Macrobrachium rosenbergii) prawns. Effect of SC and SCH on the state of water and denaturation of lizard fish (Saurida wanieso) myofibrillar protein (Mf) at concentrations of 5\% (dry weight/wet weight) were assessed based on water activity (Aw) and changes in Mf Ca-ATPase activity during dehydration. The effect was compared with untreated Mf (control) and Mf containing glucose. The Aw of Mf for each SCH was remarkably lower than the Mf with SC and control. The Mf with SCH showed a remarkably high level of inactivated Ca-ATPase activity, followed by Mf with SC and the control. Mf with glucose showed slightly higher inactivated Ca-ATPase activity than SCH, reaching Aw levels of 0.65 , before rapidly decreasing. These findings revealed that $\mathrm{SCH}$ contributed to the retardation eff ect on dehydration-induced denaturation of Mf by stabilizing hydrated water molecules surrounding the Mf.
\end{abstract}

Keywords: chitin, hydrolysis, fish myofibrils, water activity, Ca-ATPase activity

\section{Introduction}

Thailand exports more than 250,000 tons of shrimp products annually with black tiger prawn, a marine shrimp, accounting for 50\% (Fishery Information Technology Center, 2001). Giant freshwater prawn is the biggest freshwater shrimp that has become a commercially important species of crustacean cultured extensively throughout Southeast Asia. Aquaculture of giant freshwater prawn in Thailand accounted for 4.8\% (13,300 tons) of total freshwater culture in 2001 (Fishery Information Technology Center, 2001). Endeavour prawn, a marine shrimp, is imported from Australia and re-exported after processing in Thailand. The wastes from shrimp processing plants have been estimated at about $35-45 \%$ of total weight/shrimp. The considerable quantity of shell waste from processing of shrimp has become a major concern for seafood processing plants. Most of this waste is used as animal feed but these by-products are an important source of chitin.

Chitin is a natural polysaccharide that is abundantly present as a structural compound in shell of crustaceans such as crabs and shrimps (Fereidoon and Jozef, 1991; Ferrer et al., 1996; Kungsuwan et al., 1996; Kurita, 2001). Chitin and chitosan are insoluble in water at neutral $\mathrm{pH}$ (Ilyina et al., 1999; Kurita, 2001). The hydrolysis of chitin or chitosan produces oligosaccharides consisting of $\beta$ - $(1 \rightarrow$

E-mail: hara@net.nagasaki-u.ac.jp 4)-linked $N$-acetyl-D-glucosamine (2-acetamido-2-deoxy-Dglucose: GlcNAc) or glucosamine (2-amino-2-deoxy-Dglucose: GlcN), which are currently attracting the attention of food scientists because of their chemical behaviors, physical properties and biological functions. The oligosaccharides from chitin and chitosan exhibit significant physiological functions including the induction of phytoalexins, antimicrobial activity, and immune enhancing activity (Kurita, 2001). The oligosaccharides prepared by acid hydrolysis are promising as medicines, diagnostic drugs, fungicides and food additives (Shimoda et al., 1996; Weiner, 1992).

Dehydration is the oldest method for preserving food by removal of water. Unfortunately, dehydration not only vaporizes water but it also causes marked changes in meat quality by causing a decrease of water retention and solubility of protein (Migita et al., 1956; Suzuki, 1971; Hanafusa, 1973), resulting in a tough, dry and fibrous fish muscle texture. Water is the main component of biological materials that plays an important role in determining their shape, structure, physical and chemical composition (Maguer, 1987). Water in meat is closely associated with functional of protein and structure (Kauzmann, 1959; Nemethy and Scheraga, 1962). Hamm (1963) has estimated that $70 \%$ of the water content of fresh meat is bound by the myofibrillar protein, $20 \%$ by the sarcoplasm and $10 \%$ by the connective tissues. Thus, the myofibrillar proteins appear to be the main water-binding 
components in muscle. Myofibrillar protein constitutes $66-77 \%$ of the total protein in fish meat and plays an important role in coagulation and gel formation (Suzuki, 1981). However, the amount of water in a product is not as important to its shelf life as its water activity (Aw) is. Since the free water at the capillary layer is an important resource for enzymatic reactions and growth of microorganisms (Drapron, 1985; Jakobseb, 1985; Leistner and Rodel, 1975; Richard-Molard et al., 1985) it is also one of the major causes of the denaturation of protein. To reduce the mobilization of water in protein and inhibit this unwanted denaturation, many additives such as polysaccharides, phosphates, organic acids, protein hydrolysates, amino acids and sugars have been reported as effective (Romero et al., 1998; Kanna et al., 1972; Inada et al., 1992; Migita et al., 1956; Matsuda, 1971; Matsuda, 1979 a, b; Yamashita et al., 2002; Zhang et al., 2002). The addition of sugars can stabilize proteins from dehydrationinduced denaturation (Matsuda, 1979a, b; Carpenter et al., 1987, 1988). However, sugars can impart a sweet taste and can change the final product color considerably, and this has led to a search for alternative cryoprotectants (Carvajal et al., 1999; Herrera and Sampedro, 2002; Park and Lanier, 1987; Sultanbawa and Li-Chan, 1999).

Decreased freshness and protein deterioration occur very quickly in lizard fish (Saurida spp.) kept in ice storage, and stability in frozen storage is very low (Holmes et al., 1992; Nozaki et al., 1978; Yasui and Lim, 1987). In the South East Asian region, most of lizard fish is used for dried fisheries products and low-quality minced meat for low-priced fishcake products. Thus, myofibrillar protein of lizard fish was selected for use in this study.

Romero et al. (1998) and Yamashita et al. (2002) have reported the effects of chitin and oligosaccharides from crab and squid on the state of water and retardation of dehydration induced-denaturation of lizard fish myofibrillar protein. Therefore, the present study was designed to utilize shrimp chitin and its oligosaccharides as a natural preservative and food additive and to investigate of their effects on the state of water and dehydration-induced denaturation of lizard fish myofibrillar protein.

\section{Materials and Methods}

Materials Frozen shrimp shells of black tiger (Penaeus monodon), endeavour (Metapenaeus endeavouri) and giant freshwater (Macrobrachium rosenbergii) prawns were obtained from a seafood processing factory in Thailand (Hoko Fishing Co. Ltd., Samutsakorn). Fresh lizard fish (Saurida wanieso) was purchased from the Nagasaki wholesale fish market, Japan.

Preparation of shrimp chitin Chitin was isolated according to the method of Hackman (1954) with a slight modification. Shrimp shells were washed, dried and ground to 40 mesh. The ground sample was demineralized with 20 volumes of $2 \mathrm{~N} \mathrm{HCl}$ solution at room temperature for $60 \mathrm{~h}$ with replacement of the $\mathrm{HCl}$ solution every $12 \mathrm{~h}$ and subsequent stirring in 20 volumes of $1 \mathrm{~N}$ $\mathrm{NaOH}$ solution at $60^{\circ} \mathrm{C}$ for $48 \mathrm{~h}$ in order to remove protein.
The $\mathrm{NaOH}$ solution was changed at $6,12,24$ and $36 \mathrm{~h}$. The sample was then washed with distilled water until the $\mathrm{pH}$ became neutral and was soaked overnight in 5 volumes of $95 \%$ ethanol in order to remove fat and color substances. After the samples were dried in a hot air oven at $60^{\circ} \mathrm{C}$ for $48 \mathrm{~h}$, the fine flake shrimp chitin was obtained.

The degree of acetylation of shrimp chitin The degree of acetylation (DA) of chitin was determined by the method of Brugnerotto et al. (2001) using a Fourier Transform InfraRed spectrometer (Excalibur FTS 3000 MXN, Digilab, Tokyo, Japan) with Bio-Rad Digilab Win-IR Pro Software.

The mean molecular weight and degree of polymerization of shrimp chitin Due to a limitation of solubility, chitin samples were changed to chitosan before further analyses. Samples were de-acetylated with $50 \% \mathrm{NaOH}$ solution for $1 \mathrm{~h}$ at $110^{\circ} \mathrm{C}$. De-acetylation was carried out twice to ensure complete solubility. The molecular weight of chitosan samples $(2 \mathrm{mg} / \mathrm{ml})$ was estimated by gel permeation chromatography (GPC) using pullulan (MW 5,900-788,000) as a standard. Analysis was performed on an Ultrahydrogel linear column $(7.8 \mathrm{ID} \times 300 \mathrm{~mm}$, Waters, USA) connected in line with a Waters GPC apparatus. Spectra of chitosan samples (solid state) were recorded on a Bruker DPX-300 Nuclear Magnetic Resonance Spectrometer (NMR) at $75 \mathrm{MHz}\left(25^{\circ} \mathrm{C}\right)$. The degree of polymerization of $\mathrm{SC}$ was calculated from the number-average molecular weight $(\mathrm{Mn})$ divided by molecular weight of repeating unit.

Preparation of chitin hydrolysate The shrimp chitin hydrolysate was prepared according to the modified method of Rupley (1964). The shrimp chitin was stirred with $12 \mathrm{~N} \mathrm{HCl}$ for $7 \mathrm{~h}$ in a water bath at $40^{\circ} \mathrm{C}$. The hydrolytic reaction was terminated by adding 6 volumes of distilled water and neutralized by adding $25 \% \mathrm{NaOH}$ solution. After salt was eliminated by desalting machine (Micro Acilyzer G3, Asahi Kasei Inc., Kanagawa, Japan), the desalted sample was subjected to Millipore ultrafiltration (Minitan, Pellicon XL, Billerica, USA) using a molecular weight (MW) cutoff at 1.0-104. The filtrate was subjected to a spray dryer (IGA 32, Yamato Scientific Inc., Tokyo, Japan) and powder shrimp chitin hydrolysates were obtained.

Proximate composition and properties of shrimp chitin and shrimp chitin hydrolysate Moisture, crude protein, crude lipid and ash content of the SC and $\mathrm{SCH}$ were analyzed by the methods of atmospheric heat drying at $105^{\circ} \mathrm{C}$ (AOAC, 1984), Lowry's method (Lowry et al., 1951), a Soxhlet system and heating in a furnace $\left(600^{\circ} \mathrm{C}\right)$, respectively. Sodium chloride was determined by a salt analyzer (SAT-2A, TOA Electronics, Ltd., Japan). The amounts of SC and $\mathrm{SCH}$ were obtained by subtracting the corresponding crude protein, crude lipid and ash content from the total amount of the material.

The molecular weight distribution of the $\mathrm{SCH}$ was estimated by measuring the absorbance at $210 \mathrm{~nm}$ for acetyl residues derived by separation of the oligosaccharides on a Bio-Gel P-6 column (inner diameter $14 \mathrm{~mm}$, length 100 
$\mathrm{mm}$ ) using $\mathrm{N}$-acetylglucosamine (MW 221) as a standard. The sample was dispersed in distilled water at a concentration of $4 \mathrm{mg} / \mathrm{ml}$, and a $2 \mathrm{ml}$ sample was introduced into the column. The sample was eluted with distilled water at a flow rate of $10 \mathrm{ml} / \mathrm{h}$. An automatic fraction collector collected $1 \mathrm{ml}$ aliquots of each separated sample. The number-average molecular weight of $\mathrm{SCH}$ was calculated from total weight of all molecules (total peak area) distributed in each $\mathrm{SCH}$ divided by the total number of molecules (number of peaks). Average degree of polymerization of the $\mathrm{SCH}$ was calculated from the numberaverage molecular weight divided by the molecular weight of the standard, N-acetylglucosamine.

Preparation of fish myofibrillar protein Fish myofibrillar protein (Mf) was prepared according to the method of Katoh et al. (1977) with a slight modification (Nozaki et al., 1991). Minced lizard fish meat was washed 3 times with 5 volumes of $0.1 \mathrm{M} \mathrm{KCl}-20 \mathrm{mM}$ Tris-maleate buffer ( $\mathrm{pH} 7.0$ ), then homogenized with 3 volumes of same buffer and passed through nylon net $(16 \mathrm{~mm})$ to remove connective tissues. Subsequently, Triton X-100 at 1\% final concentration was added and left stand for 30 minutes. To remove the Triton $\mathrm{X}-100$ solution, the mixture was centrifuged at $1,400 \times g$ for $10 \mathrm{~min}$. The residue was washed with the same buffer, stirred and centrifuged until the supernatant became clear. The precipitate was washed again with 5 volumes of cold distilled water and centrifuged at $5,000 \times g$ for $10 \mathrm{~min}$. Finally, the excess water was removed by centrifugation at $27,000 \times g$ for 20 min. The obtained residue was used as Mf. The approximate components of the Mf used in the present study were $88.74 \%$ water, $10.66 \%$ crude protein, $0.14 \%$ crude lipid and $0.46 \%$ ash.

Sample preparation Shrimp chitin and their oligosaccharides were added to Mf at a level of 5\% (dry wt/wet wt). The samples were then mixed and ground using a mortar and pestle for $20 \mathrm{~min}$ at $5{ }^{\circ} \mathrm{C}$. The mixtures were put in cellophane bags, sealed, embedded in silica gels inside desiccators and kept in a cold room with occasional replacement of the silica gels for dehydration. Further dehydration was carried out when the moisture content of samples reached approximately $10 \%$ by reducing pressure in a desiccator. Mf with glucose and without additives (control) was used in order to compare the effect of $\mathrm{SC}$ and SCH. All samples were treated identically.

Determination of water activity and moisture content The Mf samples were serially collected and the water activity (Aw) was measured by the indirect equilibrium vapor pressure method (Akiba, 1974) using oil manometer at $20^{\circ} \mathrm{C}$. Moisture content of the samples during the dehydration process was determined using atmospheric heat drying at $105^{\circ} \mathrm{C}(\mathrm{AOAC}, 1984)$.

State of water analysis Desorption isotherms were obtained by plotting values of moisture content against those of Aw. The inflection point was obtained by B.E.T. analysis (Brunauer et al., 1938)0The moisture content at this point was defined as the amount of monolayer sorbed water $\left(\mathrm{M}_{1}\right)$. According to Bull's report (1944), the moisture content at the inflection point of $\mathrm{Aw}$, which corre- sponds to the minimal point on (M/Aw)-Aw, was defined as the amount of multilayer sorbed water $\left(\mathrm{M}_{2}\right)$. The sorption surface area (S) of Mf in monolayer-sorbed water was calculated using the following equation:

$$
\mathrm{S}=\mathrm{M}_{1} \times \mathrm{Sw} \times \mathrm{N} /\left(\mathrm{Mw} \times 10^{3}\right)
$$

where, $\mathrm{S}=$ the sorption area per $\mathrm{mg}$ of sorbed water $\left(\mathrm{m}^{2} / \mathrm{mg}\right), \mathrm{M}_{1}=$ the amount of monolayer sorbed water $(\mathrm{mg} / \mathrm{mg}$ of dried matter), $\mathrm{Sw}=$ the cross-sectional area of water molecules $\left(10.8 \AA^{2}\right), \mathrm{N}=$ Avogadro's number $(6.02 \times$ $\left.10^{23} / \mathrm{mol}\right)$ and $\mathrm{Mw}=$ molecular weight of water $(18 \mathrm{~g} / \mathrm{mol})$.

Determination of fish Myofibrillar protein Ca-ATPase activity One gram of the dehydrated Mf was taken out at different moisture content level, suspended in 30 volumes of $0.1 \mathrm{M} \mathrm{KCl}-20 \mathrm{mM}$ Tris maleate buffer ( $\mathrm{pH} 7.0)$ and left to stand overnight at $5^{\circ} \mathrm{C}$ for water restoration. It was then homogenized (Nichion-irika Kikai Seisakusho Histocolon $\mathrm{NS}-560)$ at $1,000 \mathrm{rpm}$ for $1 \mathrm{~min}$ and centrifuged at $750 \times \mathrm{g}$ for $10 \mathrm{~min}$. The Mf precipitate was suspended in the same buffer. The protein concentration was determined using the biuret method (Gornall et al., 1949) using bovine serum albumin (fraction V) as the standard. The Mf CaATPase activity was determined according to the method of Katohet al. (1977). The activity was tested at $25^{\circ} \mathrm{C}$ in a reaction medium composed of $100 \mathrm{mM} \mathrm{KCl,} 5 \mathrm{mM} \mathrm{CaCl}_{2}, 25$ $\mathrm{mM}$ Tris-maleate (pH 7.0), $1 \mathrm{mM} \mathrm{ATP}$, and $200-400 \mu \mathrm{g} / \mathrm{ml}$ Mf. This reaction was terminated after $5 \mathrm{~min}$ by adding $30 \%$ TCA solution at the final concentration of $5 \%$ and free inorganic phosphate was measured by colorimetry. Activity was indicated by $\mu \mathrm{mol}$ per min of the inorganic phosphorus (Pi) released from $1 \mathrm{mg}$ of myofibrillar protein.

\section{Results and Discussion}

Proximate composition, number-average molecular weight, average degree of polymerization and degree of acetylation of shrimp chitin and shrimp chitin hydrolysate The chemical composition and properties of shrimp chitin (SC) are presented in Table 1. Sugar substrate was the major component, accounting for over 99\% of all SC samples. Crude protein, crude lipid and ash accounted for less than $0.004 \%, 0.05-0.18 \%$ and $0.23-0.58 \%$, respectively. This result indicated that chitin obtained in the present study has high purity. The number-average molecular weight of $\mathrm{SC}$ ranged from $1.32 \times 10^{5}$ to $1.58 \times 10^{5}$. The average degree of polymerization was lowest in black tiger prawn $\left(4.93 \times 10^{2}\right)$, followed by giant freshwater prawn $\left(6.05 \times 10^{2}\right)$ and endeavour prawn $\left(7.23 \times 10^{2}\right)$. The degree of $N$ acetylation of SC ranged from 82.22 to $85.70 \%$, which is in agreement with the finding of Kurita (2001) and Romero et al. (1998).

The chemical composition and properties of shrimp chitin hydrolysates $(\mathrm{SCH})$ are presented in Table 2. Sugar substances were the main component of all $\mathrm{SCH}$ samples. The total amount of crude protein, crude lipid and ash contents were less than $1 \%$. Sodium chloride was less than $0.002 \%$. The molecular weight distribution of $\mathrm{SCH}$ is presented in Fig. 1. The monomer was the major component of all SCH, accounting for $76.07 \%$, $69.55 \%$, and $62.14 \%$ in the $\mathrm{SCH}$ of black tiger prawn, 
Table 1. Chemical composition and properties of chitin from various shrimp species.

\begin{tabular}{lccc}
\hline Composition and properties & $\begin{array}{c}\text { Black tiger } \\
\text { prawn }\end{array}$ & $\begin{array}{c}\text { Endeavour } \\
\text { prawn }\end{array}$ & $\begin{array}{c}\text { Giant freshwater } \\
\text { prawn }\end{array}$ \\
\hline Sugar substrate (chitin) \pm S.D. ${ }^{* 1}$ & $99.24 \pm 0.09$ & $99.34 \pm 0.15$ & $99.72 \pm 0.03$ \\
Ash \pm S.D. ${ }^{* 1}$ & $0.58 \pm 0.09$ & $0.55 \pm 0.17$ & $0.23 \pm 0.02$ \\
Crude lipid \pm S.D. ${ }^{* 1}$ & $0.18 \pm 0.01$ & $0.11 \pm 0.01$ & $0.05 \pm 0.01$ \\
Crude protein ${ }^{* 2}$ & trace & trace & trace \\
Number-average molecular weight $(\mathrm{Mn})$ & $1.08 \times 10^{5}$ & $1.58 \times 10^{5}$ & $1.32 \times 10^{5}$ \\
Average degree of polymerization & $4.93 \times 10^{2}$ & $7.23 \times 10^{2}$ & $6.05 \times 10^{2}$ \\
Degree of acetylation $(\%) \pm$ S.D. & $84.6 \pm 1.22$ & $85.7 \pm 0.24$ & $82.22 \pm 0.91$ \\
\hline
\end{tabular}

S.D. = Standard deviation $(n=5)$.

$* 1 \quad \mathrm{~g} / 100 \mathrm{~g}$ of dried matter.

${ }^{*} 2<0.004 \mathrm{~g}$

Table 2. Chemical composition and properties of chitin hydrolysates from various shrimp species.

\begin{tabular}{lccc}
\hline Composition and properties & $\begin{array}{c}\text { Black tiger } \\
\text { prawn }\end{array}$ & $\begin{array}{c}\text { Endeavour } \\
\text { prawn }\end{array}$ & $\begin{array}{c}\text { Giant freshwater } \\
\text { prawn }\end{array}$ \\
\hline Sugar substance \pm S.D. ${ }^{* 1}$ & $99.33 \pm 0.04$ & $99.13 \pm 0.04$ & $99.23 \pm 0.05$ \\
Ash \pm S.D. ${ }^{* 1}$ & $0.61 \pm 0.03$ & $0.81 \pm 0.03$ & $0.70 \pm 0.06$ \\
Crude lipid \pm S.D. ${ }^{* 1}$ & $0.06 \pm 0.01$ & $0.06 \pm 0.01$ & $0.07 \pm 0.01$ \\
Crude protein ${ }^{* 2}$ & trace & trace & trace \\
$\mathrm{NaCl}^{* 3}$ & trace & trace & trace \\
Number-average molecular weight $(\mathrm{Mn})$ & 351 & 383 & 420 \\
Average degree of polymerization & 1.59 & 1.73 & 1.90 \\
\hline
\end{tabular}

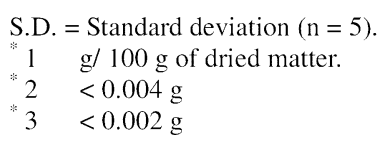

endeavour prawn and giant freshwater prawn, respectively. The SCH of black tiger prawn exhibited monomer to trimer, the $\mathrm{SCH}$ of endeavour prawn exhibited monomer to tetramer and the $\mathrm{SCH}$ of giant freshwater prawn exhibited monomer to pentamer. Thus, $\mathrm{SCH}$ of black tiger prawn showed the lowest number-average molecular weight, while giant freshwater prawn showed the highest number-average molecular weight among the shrimp species (Table 2). The average degree of polymerization of SCH was 1.59 to 1.90 .

Water activity and state of water The desorption isotherms of dehydrated Mf containing SC and SCH are presented in Fig. 2. The desorption isotherms of all samples showed a sigmoid curve with two inflection points at Aw of $0.05-0.15$ and $0.5-0.7$, and belonged to type B sorption isotherms as classified by Shibasaki et al.(1967). The curves were similar to those of Atka mackerel meat (Akiba, 1961), carp actomyosin (Nakano, 1987), fractured meat (Suzuki, 1971) and white croaker myofibrils (Nozaki et al., 1991). The desorption isotherms of dehydrated Mf containing SC from the three shrimp species were similar and exhibited few Aw values higher than those of the control irrespective of shrimp species at the same moisture content. These results indicated that SC could not immobilize water in Mf. In addition, SC might interrupt bonding between Mf and water since chitin possibly competed with water for protein binding resulted in an increase of free water. Kauzmann (1959) reported that denaturation may cause considerable changes in the ability of a protein to bind other substances.

The desorption isotherm of dehydrated Mf containing SCH for the three shrimp species showed a similar tendency, and showed lower Aw values than that of the control at the same moisture level. These results indicated that the free water in Mf containing SCH was immobilized and changed into bound water to some extent. It is revealed that after the main chain of SC was cleaved, the hydrophilic $\mathrm{OH}$ residues of $N$-acetyl-D-glucosamine were exposed and made interaction with water in Mf possible. Matsumoto (1980) hypothesized that the cryoprotectant 

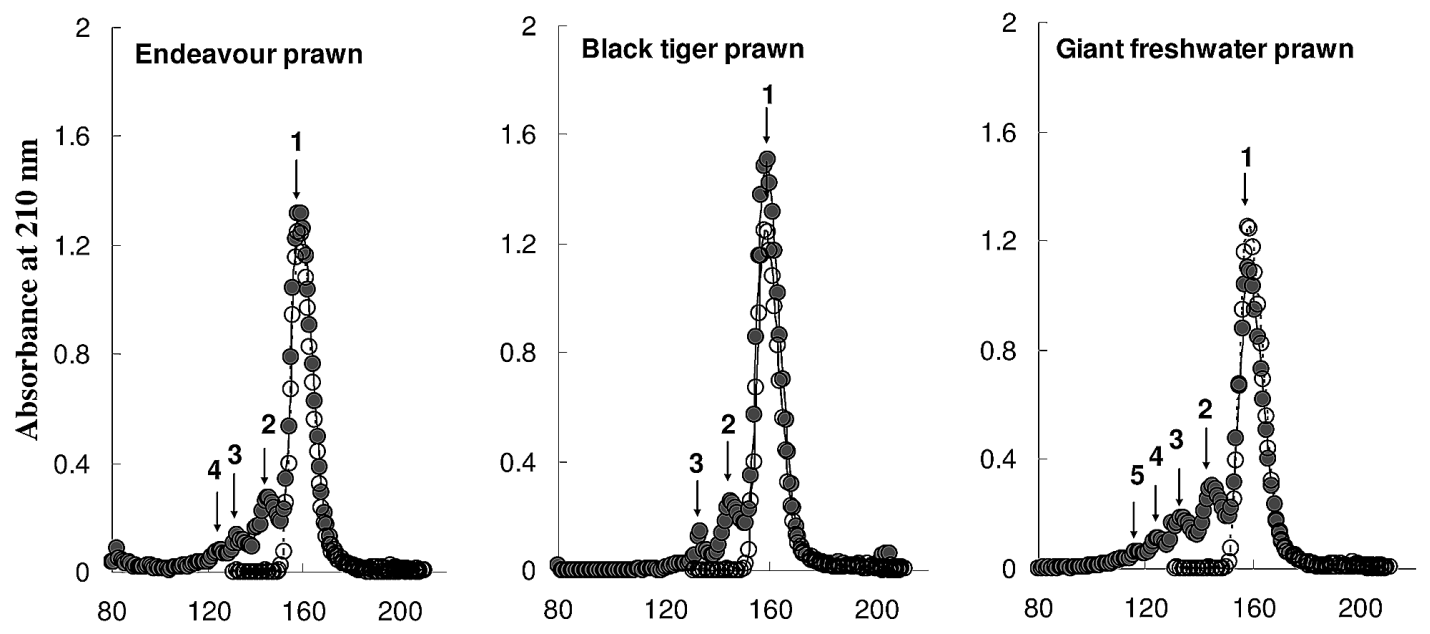

Fraction No.

Fig. 1. Gel chromatogram on Bio-Gel P-6 of various shrimp chitin hydrolysates. Eluent: water. Flow rate: $10 \mathrm{ml} / \mathrm{h}$. Fraction volume: $1 \mathrm{ml} /$ tube. Symbol: - std. $N$-acetylglucosamine (GlcNAc), oligomers. The numbers above the peaks denote the elution peaks of oligomers; (1) monomer, (2) dimmer, (3) trimer, (4) tetramer, (5) pentamer.
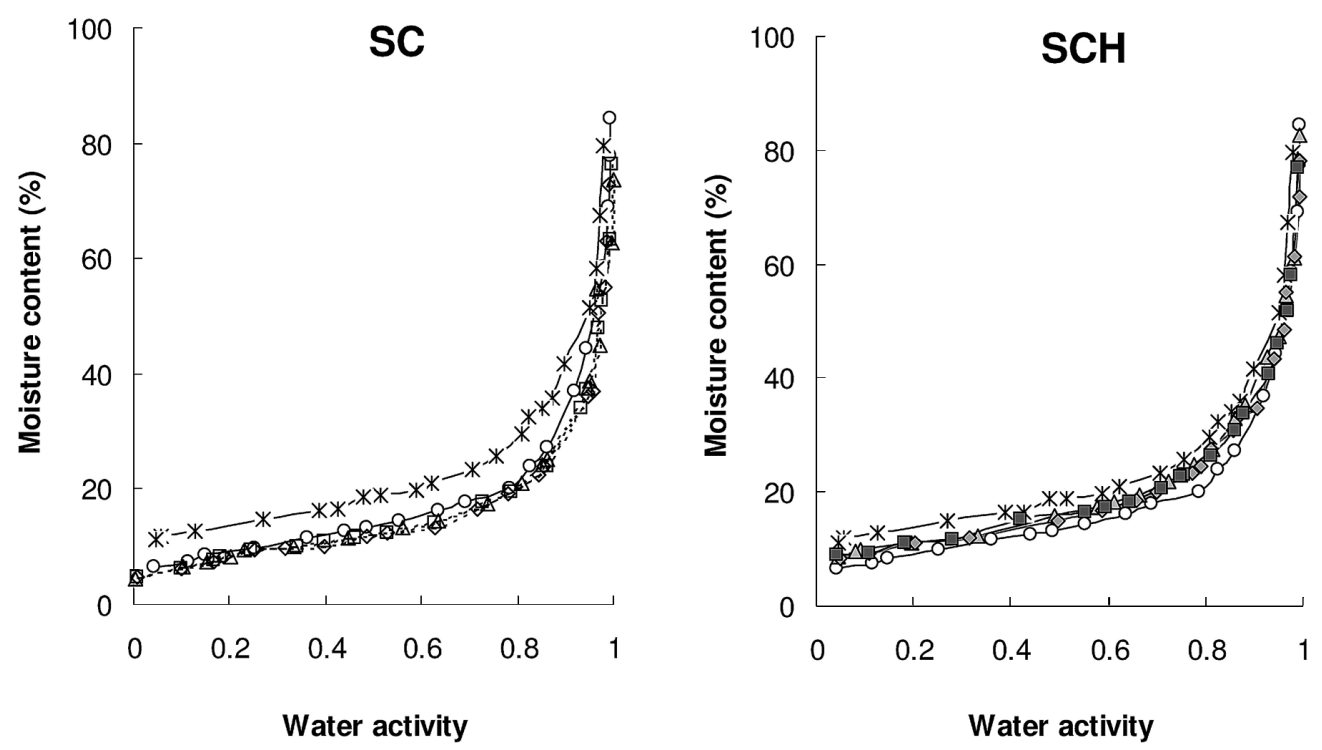

Fig. 2. Desorption isotherms of lizard fish myofibrils at $20^{\circ} \mathrm{C}$ in the presence of shrimp chitin, shrimp chitin hydrolysates, glucose and control. Control consisted of myofibrils without additives. Symbols:

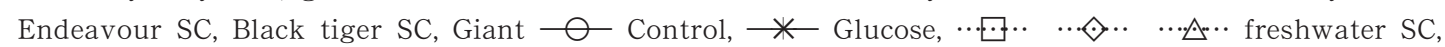

$\multimap$ Endeavour SCH, $\multimap$ Black tiger SCH, $\longleftarrow$ Giant freshwater SCH.

molecules (sugars) may bind or associate with protein molecules at a functional group either by ionic or hydrogen bonds. Thus, each protein molecule is coated by the cryoprotectant. These results led us to conclude that $\mathrm{SCH}$ has the same mechanisms as sugars. The Mf containing glucose showed the lowest Aw value at all moisture content levels and this might be due to the increased amount of the hydrophilic $\mathrm{OH}$ residues in glucose compared to hydrolysates. The suppressive effect of sugars on protein denaturation depends on the sugar composition (Matsuda, 1979a, b; Matsuda and Arai, 1987;
Matsumoto et al., 1985), such as the number of hydrophilic OH residues (Noguchi, 1992; Ooizumi, Hashimoto et al., 1981).

To determine the amount of bound water in the Mf, the state of water was analyzed. The monolayer sorbed water $\left(\mathrm{M}_{1}\right)$, multilayer sorbed water $\left(\mathrm{M}_{2}\right)$ and sorption surface area $(\mathrm{S})$ were calculated from the desorption isotherms at $20^{\circ} \mathrm{C}$ of the control and the Mf containing $\mathrm{SC}, \mathrm{SCH}$ and glucose results are presented in Table 3. The $\mathrm{M}_{1}, \mathrm{M}_{2}$, and $\mathrm{S}$ of the control were $7.65 \mathrm{~g} / 100 \mathrm{~g}, 15.5 \mathrm{~g} / 100 \mathrm{~g}$, and $0.30 \mathrm{~m}^{2} /$ $\mathrm{mg}$, respectively. The Mf containing glucose exhibited 
Table 3. Amount of monolayer, multilayer water and sorption surface area of lizard fish myofibrillar protein to which $5.0 \%$ of various shrimp chitin (SC) and shrimp chitin hydrolysate (SCH) from desorption isotherm at $20^{\circ} \mathrm{C}$ had been added.

\begin{tabular}{lcccccc}
\hline \multirow{2}{*}{ Sample } & \multicolumn{2}{c}{$\begin{array}{c}\text { Monolayer } \\
\text { water }\end{array}$} & \multicolumn{2}{c}{$\begin{array}{c}\text { Multilayer } \\
\text { water }\end{array}$} & $\mathrm{M}_{2} / \mathrm{M}_{1}$ & $\begin{array}{c}\text { Sorption } \\
\text { surface area }\end{array}$ \\
\cline { 2 - 5 } & $\mathrm{M}_{1}{ }^{* 1}$ & $\mathrm{Md}_{1}{ }^{* 3}$ & $\mathrm{M}_{2}{ }^{* 2}$ & $\mathrm{Md}_{2}{ }^{* 3}$ & & \\
\hline Control & 7.65 & 0.08 & 15.50 & 0.18 & 2.03 & 0.30 \\
Glucose & 11.65 & 0.13 & 22.55 & 0.29 & 1.94 & 0.48 \\
Sucrose & 7.27 & 0.08 & 15.89 & 0.19 & 2.19 & 0.28 \\
Endeavour SC & 7.30 & 0.08 & 14.45 & 0.17 & 1.98 & 0.28 \\
Black tiger SC & 7.46 & 0.08 & 14.69 & 0.17 & 1.97 & 0.29 \\
Giant freshwater SC & 7.44 & 0.08 & 14.60 & 0.17 & 1.96 & 0.29 \\
Endeavour SCH & 9.82 & 0.11 & 19.09 & 0.24 & 1.94 & 0.39 \\
Black tiger SCH & 9.22 & 0.10 & 18.50 & 0.23 & 2.01 & 0.37 \\
Giant freshwater SCH & 9.32 & 0.10 & 20.00 & 0.25 & 2.15 & 0.37 \\
\hline
\end{tabular}

\footnotetext{
${ }^{* 1}$ Moisture content ( $\mathrm{g} / 100 \mathrm{~g}$ of sample) estimated by B.E.T. analysis.

${ }^{* 2}$ Moisture content ( $\mathrm{g} / 100 \mathrm{~g}$ of sample) estimated by Bull's analysis.

${ }^{*}$ Moisture content ( $\mathrm{g} / \mathrm{g}$ of dried matter).

${ }^{* 4}$ Sorption surface area $\left(\mathrm{m}^{2} / \mathrm{mg}\right.$ of dried matter).
}

the highest $\mathrm{M}_{1}, \mathrm{M}_{2}$, and $\mathrm{S}$ values $(11.65 \mathrm{~g} / 100 \mathrm{~g}, 22.55 \mathrm{~g} / 100$ $\mathrm{g}$, and $\left.0.48 \mathrm{~m}^{2} / \mathrm{mg}\right)$. Mf containing each kind of $\mathrm{SC}$ showed a slightly lower $\mathrm{M}_{1}, \mathrm{M}_{2}$, and $\mathrm{S}(7.3-7.46 \mathrm{~g} / 100 \mathrm{~g}$, $14.45-14.69 \mathrm{~g} / 100 \mathrm{~g}$, and $0.28-0.29 \mathrm{~m}^{2} / \mathrm{mg}$ ) than those of control. Whereas, Mf containing $\mathrm{SCH}$ had values higher than those of the control $(9.22-9.82 \mathrm{~g} / 100 \mathrm{~g}, 18.5-20.0 \mathrm{~g} / 100$ $\mathrm{g}$, and $0.37-0.39 \mathrm{~m}^{2} / \mathrm{mg}$ ), respectively, but lower than those of Mf containing glucose. The increment of $\mathrm{M}_{1}$ and $\mathrm{M}_{2}$ in the Mf containing SCH supported the hypothesis that it exhibited a strong bonding capacity between water and $\mathrm{SCH}$ which can retard the effect of dehydration-induced denaturation of Mf. The Mf containing giant freshwater $\mathrm{SCH}$ exhibited the highest $\mathrm{M}_{2}$ values, followed by $\mathrm{Mf}$ containing endeavour SCH and Mf containing black tiger $\mathrm{SCH}$, respectively. The functional properties of chitin and chitosan oligomers have clearly revealed their high dependency on the degree of polymerization (Hirano and Nagano, 1989; Suzuki, 1996). Yamashita et al. (2002) have also reported that hydrolysates from king crab chitin (Paralithodes camtschtica), which exhibit the highest average degree of polymerization, showed the highest $\mathrm{M}_{2}$ values for dehydrated lizard fish Mf. The amounts of $\mathrm{M}_{1}$ of all Mf containing SCH were similar. The finding that the sorption surface area (S) of Mf containing SC was similar to that of the control while those of Mf containing $\mathrm{SCH}$ and glucose were increased supported the hypothesis that water molecules were captured by $\mathrm{SCH}$ or glucose. The $\mathrm{M}_{2} / \mathrm{M}_{1}$ ratio of all samples in the present study ranged from 1.94-2.19, which corresponded with $\mathrm{M}_{2} / \mathrm{M}_{1}$ ratio (1.5-2.0) for various proteins (Bull, 1944).

Changes in Myofibrillar Ca-A TPase activity The effect of $\mathrm{SC}$ and $\mathrm{SCH}$ on the dehydration-induced denaturation of Mf was assessed in terms of Mf Ca-ATPase activity. The correlation between relative Mf Ca-ATPase activity to the initial value and $\mathrm{Aw}$ is shown in Fig. 3. The Mf Ca-ATPase activity of the control decreased rapidly by more than $90 \%$ in the capillary condensation domain from the initial activity at Aw levels of 0.85 , before gradually decreasing in the multilayer to monolayer range.
This finding suggested that the interaction between protein and water molecules was closely correlated with the degree of denaturation of Mf. Since Mf containing SC was not able to interact with water molecules surrounding Mf, its relative Ca-ATPase activity exhibited a similar tendency to that of the control. At the Aw level of 0.85 , Ca-ATPase activity of Mf containing SC decreased by more than $75 \%$ of the initial value while the activity of Mf containing SCH only decreased $10-20 \%$ of the initial value. Consequently, at the multilayer to monolayer range, Ca-ATPase activity of Mf containing $\mathrm{SC}, \mathrm{SCH}$ and the control gradually decreased except for Mf containing glucose that kept high rate on decrement and finally remained activity lower than that of Mf containing $\mathrm{SCH}$. The giant freshwater $\mathrm{SCH}$ exhibited the highest inhibiting effect on the dehydration-induced denaturation of myofibrils, followed by endeavour $\mathrm{SCH}$ and black tiger $\mathrm{SCH}$, respectively. Since water is recognized as an important functional factor concerning numerous phenomena in regard to the quality of food, these findings showed that $\mathrm{SCH}$ can prevent the destruction of hydrogen bonds and/or hydrophobic bonds between water molecules and protein during dehydration. Back et al. (1979) noted that hydrophobic interactions between pairs of hydrophobic groups are stronger in sucrose or glycerol solutions than in pure water. They concluded that this is the mechanism by which sugars may stabilize proteins to heat denaturation. The hydrolysates from shrimp chitin in this present study seem to demonstrate the same mechanism as sugars. At Aw levels of 0.02, the Ca-ATPase activity of Mf containing $\mathrm{SCH}$ prepared from giant freshwater prawns showed the highest remaining inactivated activity $(70 \%)$, followed by that of endeavour prawn $(60 \%)$, black tiger prawn $(45 \%)$ and glucose $(42 \%)$. These results showed a high correlation between hydrated water and degree of denaturation of Mf. The amount of bound water in Mf containing each kind of shrimp was $29.32 \mathrm{~g} / 100 \mathrm{~g}$ in giant freshwater prawn, $28.92 \mathrm{~g} / 100 \mathrm{~g}$ in endeavour prawn, and $27.77 \mathrm{~g} / 100 \mathrm{~g}$ in black tiger prawn. 

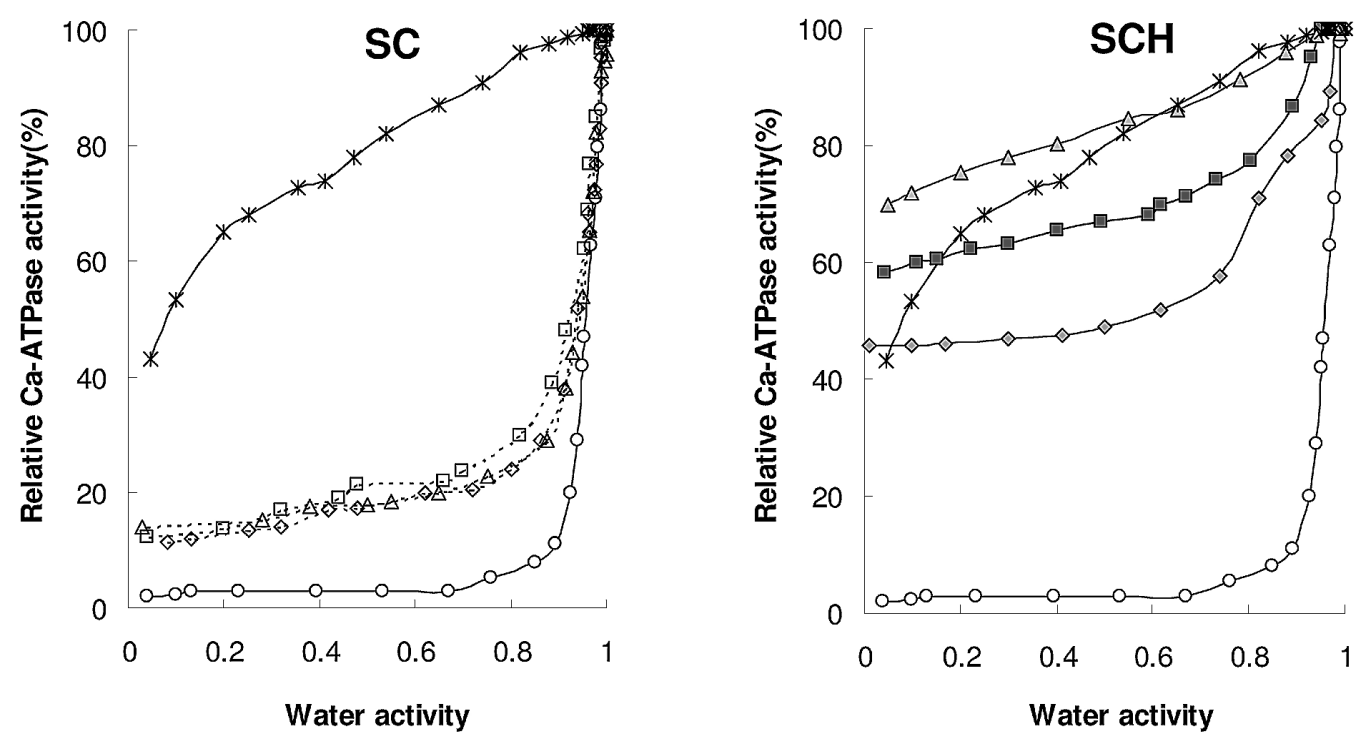

Fig. 3. Relationship between the water activity and relative Ca-ATPase activity of myofibrils added to shrimp chitin, shrimp chitin hydrolysates, glucose. Control consisted of myofibrils without additives. Symbols are same as in Fig. 2.

Drying proteins has many commercial advantages, such as lower shipping costs, more convenient storage, and usefulness in dry mix applications. A shift of surimi production from the frozen to the dried form could thus open many new applications for fish proteins and lead to their wider acceptance as food ingredients. However, during drying the water surrounding the protein molecules that stabilizes the intramolecular hydrogen and hydrophobic bonds that keep the molecule in its native structure is moved and this can lead to structural changes or denaturation. To prevent denaturation, water movement must be controlled and the proteins should be stabilized. Sucrose seems most effective during storage of the freeze-dried product and does not induce browning due to Maillard reactions. However, sucrose imparts a sweet taste and has a high caloric content. In a preliminary study we determined the effect of sucrose and sorbitol on the state of water of lizard fish Mf. Unfortunately sucrose and sorbitol could not decrease water activity of dehydrated Mf (data not shown). Glucose is the one sugar that has been reported to be a good antidenaturant, but it induces Maillard reaction as well. The $\mathrm{SCH}$ in the present study offers advantages in the reduction of sweetness and have potential application as highly functional additives in food manufacturing. Although shrimp chitin could not be immobilized water of dehydrated Mf, it did show a suppressive effect on the dehydration-induced denaturation of Mf.

\section{Conclusion}

It was found that Mf with SCH showed almost the same tendency as results of oligosaccharides from crab and squid as reported by Yamashita et al. (2002). Thus, it may be concluded that chitin oligosaccharides obtained from shrimp, crab, and squid reduced water activity in Mf and also showed a suppressive effect on the dehydration- induced denaturation of Mf. Thus, the utility of these oligosaccharides as natural food protective materials for dry or partially dry foods could stimulate more interest in food processing and preservation.

Acknowledgements This study was supported by a Grant-in-Aid from the Ministry of Education, Culture, Sports, Science and Technology of Japan.

\section{References}

Akiba, M. (1961). Studies on bound water in fish muscle. Mem. Fac. Fisheries Hokkaido University, 9, 85-179 (in Japanese).

Akiba, M. (1974). Measurement of water activity. In "Experimental Book of Marine Biological Chemistry and Food Science," ed. by T. Saito, H. Uchiyama, S. Umemoto and T. Kawabata. Koseisha Koseikaku, Tokyo, pp. 341-351 (in Japanese).

Back, J.F., Oakenfull, D. and Smith, M.B. (1979). Increase thermal stability of proteins in the presence of sugars and polyols. Biochem., 18, 5191-5196.

Brugnerotto, J., Lizardi, J., Goycoolea, F.M., Argueelles-Monal, W., Desbrieres, J. and Rinaudo, M. (2001). An infrared investigation in relation with chitin and chitosan characterization. Polymer, 42, 3569-3580.

Brunauer, S., Emmett, P.H. and Teller, E. (1938). Adsorption of gasses in multimolecular layers. J. Am. Chem. Soc., 60, 309-319.

Bull, H.B. (1944). Adsorption of water vapor by proteins. J. Am. Chem. Soc., 66, 1499-1507.

Carpenter, J.F., Crowe, L.M. and Crowe, J.H. (1987). Stabilization of phosphofructokinase with sugars during freeze-drying: characterization of enhanced protection in the presence of divalent cations. Biochim. Biophys. Acta., 923, 109-115.

Carpenter, J.F. and Crowe, J.H. (1988). The mechanism of cryoprotection of protein by solutes. Cryo., 25, 244-255.

Carvajal, P.A., MacDonald, G.A. and Lanier, T.C. (1999). Cryostabilization mechanism of fish muscle proteins by maltodextrins. Cryo., 38, 16-26.

Drapron, R. (1985). Enzyme activity as a function of water activity. In "Properties of Water in Foods," ed. by D. Simatos and L. J. Multon. Martinus Nijhoff Publishers, Netherlands, pp. 171190. 
Fereidoon, S. and Jozef, S. (1991). Isolation and characterization of nutrients and value-added products from snow crab (Chinoecetes opilio) and shrimp (Pandalus borealis) processing discards. J. Agric. Food Chem., 39, 1527-1532.

Ferrer, J., Paez, G., Marmol, Z., Ramones, E. Garcia, H. and Forster, C.F. (1996). Acid hydrolysis of shrimp-shell waste and the production of single cell protein from the hydrolysate. Bioresour. Technol., 57, 55-60.

Fishery Information Technology Center (2001). Fisheries statistic of Thailand 2001 no. 15/2004. (in Thai).

Gornall, A.G., Bardawill, T.C. and Davis, M.M. (1949). Determination of serum proteins by means of biuret reaction. J. Biol. Chem., 177, 751-766.

Hackman, R.H. (1954). Enzymic degradation of chitin and chitin esters. Austr. J. of Bio Sci., 71, 168-178.

Hamm, R. (1963). Die mikrostruktur des muskels undihere beziehung zum wasserbindungsvermogen des fleisches. Fleischwirtschaft. 15, 298.

Hanafusa, N. (1973). Biological macromolecules and water. In "Foods and Water," ed. by Jpn. Soc. Fisheries Sci. Koseisha Koseikaku, Tokyo, pp. 9-24 (in Japanese).

Herrera, J. and Sampedro, L. (2002). Effects of various cryostabilisers on protein functionality in frozen-stored minced blue whiting muscle: The importance of inhibiting formaldehyde production. Eur. Food Res. Technol., 214, 382-387.

Hirano, S. and Nagano, N. (1989). Effects of chitosan, pectic acid, lysozyme and chitinase on the growth of several phytopathogens. Agric. Biol. Chem., 53, 3065-3066.

Holmes, L.K., Noguchi, F.S. and MacDonald, A.G. (1992). The Alaska pollock resource and other species used for surimi. In "Surimi Technology," ed. by T.C. Lanier and M.C. Lee. Marcel Dekker Inc., New York, pp. 41-76.

Ilyina, V.A., Tatarinova, Y.N. and Varlamov, P.V. (1999). The preparation of low-molecular-weight chitosan using chitinolytic complex from Streptomyces kurssanovii. Process Biochem., 34, 875-878.

Inada, N., Ichikawa, H., Nozaki, Y., Hiraoka, K., Yokoyama, T. and Tabata, Y. (1992). Effects of sugar on hydration and denaturation of fish myofibrillar protein due to dehydration with silica gel. Nippon Shokuhin Kogyo Gakki, 39, 211-218 (in Japanese).

Jakobseb, M. (1985). Effect of Aw on growth and survival of Bacillaceae. In "Properties of Water in Foods," ed. by D. Simatos and L.J. Multon. Martinus Nijhoff Publishers, Netherlands, pp. 259-272.

Kanna, K., Kasuda, K. and Sakuraba, M. (1972). Denaturation of fish protein by drying IV. Bull. Tokai Reg. Fish. Res. Lab., 69, 125-131(in Japanese).

Katoh, N., Uchiyama, H., Tsukamoto, S. and Arai, K. (1977). A biological study on fish myofibrillar ATPase. Bull. Japan. Soc. Sci. Fish., 43, 857-867.

Kauzmann, W. (1959). Some factors in the interpretation of protein denaturation. Adv. Protein Chem., 14, 1-63.

Kungsuwan, A., Kiatkungwalkrai, P., Mukka, S., Chandrkrachang, S. and Stevens, W.F. (1996). Protein and chitin from shrimp biowaste by fermentation using Lactobacilli. In "Chitin Enzymology," Vol. 2 ed. by A.A.R. Muzzarelli. Atec Edizioni, Italy, pp. 573-580.

Kurita, K. (2001). Controlled functionalization of the polysaccharide chitin. Progress in Polym. Sci., 26, 1921-1971.

Leistner, L. and Rodel, W. (1975). The significance of water activity for microorganisms in meats. In "Water Relations of Foods," ed. by R.B. Duckworth. Academic Press, London, pp. 309-323.

Lowry, O.H., Rosebrough, N.J., Farr, A.L. and Randall, R.J. (1951). Protein measurement with the folin phenol reagent. J. of Biol. Chem., 193, 265-275.

Maguer, L.M. (1987). Mechanics and influence of water binding on water activity. In "Water Activity: Theory and Applications to Food," ed. by L.B. Rockland and L.R. Beuchat. Marcel Dekker, Inc., New York, pp. 1-25.

Matsuda, Y. (1971). Influence of platen temperature of freezedrying on the kamaboko-forming ability of lyophilized "KaenSurimi”. Bull. Japan. Soc. Sci. Fish., 37, 135-139.

Matsuda, Y. (1979a). Influence of sucrose on the protein denaturation of lyophilized carp myofibrils during storage. Bull. Japan. Soc. Sci. Fish., 45, 573-579.

Matsuda, Y. (1979b). Influence of sugars on the protein denaturation of lyophilized carp myofibrils during storage. Bull. Japan. Soc. Sci. Fish., 45, 737-743.

Matsuda, Y. (1981). Protein denaturation during freeze-drying of carp myofibrils. Bull. Japan. Soc. Sci. Fish., 47, 813-815.

Matsumoto, J.J. (1980). Chemical deterioration of muscle proteins during frozen storage. In "Chemical Deterioration of Proteins," ed. by J. Whitaker and M. Fujimaki. ACS Symp., Washington, pp. 95.

Matsumoto, I., Ooizumi, T. and Arai, K. (1985). Protective effect of sugar on freeze-denaturation of carp myofibrillar protein. Bull. Japan. Soc. Sci. Fish., 51 (5), 833-839.

Matsumoto, I. and Arai, K. (1987). Cooperative effect of carboxylic acid and sugar against freeze denaturation of fish myofibrillar protein. Nippon Suisan Gakk., 53, 2187-2193.

Migita, M., Juichiro, J., Matsumoto, J. and Saishu, T. (1956). On the denaturation of fish muscle proteins by dehydration. Bull. Japan. Soc. Sci. Fish., 22, 433-439.

Nakano, H. (1987). Studies on the behavior of water in myofibrillar proteins during dehydration. Doctoral Thesis, Hokkaido University, Sapporo (in Japanese).

Nemethy, G. and Scheraga, H.A. (1962). The structure of water and hydrophobic bonding in protein-III. J. Chem. Phys., 66, 1733-1789.

Noguchi, S. (1992). Binding water and free water. In "Food and Science of Water," Tokyo, pp. 227-263.

Nozaki, Y., Kanazu, R. and Tabata, Y. (1978). Freezing storage of lizardfish for kamaboko preparation. Refrig., 53, 473-480.

Nozaki, Y., Ichikawa, H. and Tabata, Y. (1991). Effect of amino acid on the state of water and ATPase activity accompanying dehydration of fish myofibrils. Nippon Suisan Gakk., 57, 15311537.

Official Methods of Analysis of the Association of Official Analytical Chemists, 14th ed. (1984). Ed. by S. Williams. Association of Official Analytical Chemists, Arlington, VA.

Ooizumi, T., Hashimoto, K., Ogura, J. and Arai, K. (1981). Quantitative aspect for protective effect of sugar and sugar alcohol against denaturation of fish myofibrils. Bull. Japan. Soc. Sci. Fish., 47 (7), 901-908.

Park, J.W. and Lanier, T.C. (1987). Combined effects of phosphates and sugar or polyol on protein stabilization of fish myofibrils. J. Food Sci., 52, 1059-1513.

Richard-Molard, D., Lesage, L. and Cahagnier, B. (1985). Xerophilic fungi and the spoilage of foods of plant origin. In "Properties of Water in Foods," eds. by D. Simatos and L.J. Multon. Martinus Nijhoff Publishers, Netherlands, pp. 273-292.

Romero, A.E., Ichikawa, H., Kakuta, M., Yamashita, Y., Goto, S., Osatomi, K. and Nozaki, Y. (1998). Effect of chitin derived from crustaceans and cephalopods on the state of water in lizard fish myofibrils and subsequent denaturation by dehydration. Fish. Sci., 64, 594-599.

Rupley, J.A. (1964). The hydrolysis of chitin by concentrated hydrochloric acid, and the preparation of low-molecularweight substrates for lysozyme. Biochim. Biophys. Acta., 83, 245-255.

Shibaki, S., Ootani, S. and Fukano, S. (1967). Studies of freezing and freeze-drying of food (part VI). Nippon Shokuhin Kogyo Gakk., 14, 296-303 (in Japanese). 
Shimoda, K., Nagajima, K., Hirastuka, Y., Nishimura, S. and Kurita, K. (1996). Efficient preparation of $\beta-(1 \rightarrow 6)-(\mathrm{GlcNAc})_{2}$ by enzymatic conversion of chitin and chito-oligosaccharides. Carbohydr. Polym., 29, 149-154.

Sultanbawa, Y. and Li-Chan, E.C.Y. (1998). Cryoprotective effects of sugar and polyol blends in ling cod surimi during frozen storage. Food Res. Int., 31 (2), 87-98.

Suzuki, T. (1971). Denaturation of fish muscle protein during dehydration. Nippon Shokuhin Kogyo Gakk., 18, 167-171.

Suzuki, T. (1981). Characteristics of fish meat and fish protein. In "Fish and Krill Protein: Processing Technology". Applied Science Publishers Ltd., London, pp. 1-61.

Suzuki, S. (1996). Studies on biological effects of water soluble lower homologous oligosaccharides of chitin and chitosan. Fragrance J., 15, 61-68.

Weiner, L.M. (1992). An overview of the regulatory status and of safety of chitin and chitosan as food and pharmaceutical ingredients. In "Advances in Chitin and Chitosan," ed. by C.J. Brine, P.A. Sandford and J.P. Zikakis. Elsevier Applied Science, London and New York, pp. 663-672.

Yamashita, Y., Zhang, N. and Nozaki, Y. (2002). Effects of chitin hydrolysate on denaturation of fish myofibrillar protein and the state of water during drying process. Nippon Shokuhin Kagaku Kaishi, 49, 368-376.

Yasui, A. and Lim, PY. (1987). Changes in chemical and physical properties of lizardfish meat during ice \& frozen storage. Nippon Shokuhin Kyogo Gakk., 34, 54-60.

Zhang, N., Yamashita, Y. and Nozaki, Y. (2002). Effect of protein hydrolysate from Antarctic krill meat on the state of water and denaturation by dehydration of lizard fish myofibrils. Fisheries Sci., 68, 672-679. 